\title{
First dinosaur record from the Marília Formation (Maastrichtian) in the Gurinhatã municipality, Minas Gerais state, Brazil
}

\author{
Ramon Cavalcanti ${ }^{1,6}$; Carlos Roberto dos Anjos Candeiro ${ }^{17}$; Stephen Louis Brusatte ${ }^{2,8}$; Kamila Luisa Nogueira Bandeira ${ }^{3,9}$; \\ Emerson Ferreira de Oliveira ${ }^{4,10}$; Luciano da Silva Vidal ${ }^{5,11}$ \& Musa Maria Nogueira Gomes ${ }^{1,12}$
}

\footnotetext{
1 Universidade Federal de Goiás (UFG), Laboratório de Paleontologia e Evolução (LABPALEOEV0), Curso de Geologia. Aparecida de Goiânia, G0, Brasil.

2 University of Edinburgh, Grant Institute, School of GeoSciences. Edinburgh, Edinburgh, Scotland.

${ }^{3}$ Universidade Federal do Rio de Janeiro (UFRJ), Museu Nacional (MN), Departamento de Geologia e Paleontologia (DGP), Laboratório de Sistemática e Taxonomia de Vertebrados Fósseis. Rio de Janeiro, RJ, Brasil.

${ }^{4}$ Universidade Estadual de Campinas (UNICAMP), Instituto de Geociências (IG), Programa de Pós-Graduação em Geologia. Campinas, SP, Brasil.

${ }^{5}$ Universidade Federal do Rio de Janeiro (UFRJ), Instituto de Geociências (IGEO), Departamento de Geologia, Laboratório de Macrofósseis, Programa de Pós-Graduação em Geologia. Rio de Janeiro, RJ, Brasil.

${ }^{6}$ ORCID: http://orcid.org/0000-0002-5686-3150. E-mail: cavalcantir.bio@gmail.com (corresponding author)

7 ORCID: http://orcid.org/0000-0002-8128-4660. E-mail: candeiro@ufg.br

${ }^{8}$ ORCID: http://orcid.org/0000-0001-7525-7319. E-mail: s.brusate@gmail.com

${ }^{9}$ ORCID: http://orcid.org/0000-0002-2744-8126. E-mail: kamilabandeira@yahoo.com.br

${ }^{10}$ ORCID: http://orcid.org/0000-0002-5150-401X. E-mail:oliveira.geoscience@gmail.com

${ }^{11}$ ORCID: http://orcid.org/0000-0001-9034-6985. E-mail: sciencevidal@gmail.com

${ }^{12}$ ORCID: http://orcid.org/0000-0001-9380-5657. E-mail: musa.maria.min@gmail.com
}

\begin{abstract}
Titanosaurs are one of the most common dinosaurs found in Cretaceous outcrops, especially in Brazil. In this article we describe a proximal portion of an ulna (Paleo-UFG/V-0039) which was found isolated Paleo-UFG/V-0039 comes from a sandstone outcrop, with fine to medium granulation, of the Marilia Formation (Bauru Group) that appears irregularly in the municipality of Gurinhatã, state of Minas Gerais, Brazil. The occurrence described here is the first dinosaur osteological remains documented in this municipality. Although incomplete, Paleo-UFG/V-0039 could be identified as an indeterminate lithostrotian titanosaur whose morphology is similar to some appendicular elements of European species than South American ones. However, the incompleteness of the specimen has difficult complex interpretations. Finally, Paleo-UFG/V-0039 highlights the importance of the Gurinhatã outcrops and other sites in this region for future discoveries.
\end{abstract}

Keywords. Sauropod; Triângulo Mineiro region; Late Cretacous; Brazil; Appendicular bones; Lithostrotian.

\section{INTRODUCTION}

In Brazil, records of dinosaurs are widely known from the Bauru Group (Late Cretaceous), mostly from the Triângulo Mineiro region, in the state of Minas Gerais (e.g., Kellner \& Campos, 2000; Campos et al., 2005; Faria et al., 2015; Bandeira et al., 2018; González-Riga et al., 2019) and from western São Paulo state (Santucci \& ArrudaCampos, 2011; Bandeira et al., 2016; Delcourt \& lori, 2018). More recently, some new findings are known from the other poorly explored regions, such as the outcrops in Goiás (Candeiro et al., 2018,2020 ). However, due to the historical and highly fossiliferous nature of the units, especially the Triângulo Mineiro area, several contributions discuss the geological and paleontological re- search performed by geoscientists in this region (e.g., Candeiro, 2007; Peyerl et al., 2015; Candeiro \& Figueiroa, 2017).

The Triângulo Mineiro region has yielded several dinosaur bones from the municipalities of Campina Verde, Uberaba, Monte Alegre de Minas, Prata and Verissimo (Fig. 1). The naturalist von Huene described the first record of sauropods from the Pontal of Triângulo Mineiro, specifically from Monte Alegre of Minas (Candeiro et al., 2019). However, those specimens collected by von Huene are nowadays lost (e.g., Kellner \& Campos, 2000). Most of these findings are isolated vertebrae attributed to sauropods (Candeiro, 2007), but mainly lithostrotian remains (Titanosauria: Neosauropoda). Although belonging to the Triângulo Mineiro region and 

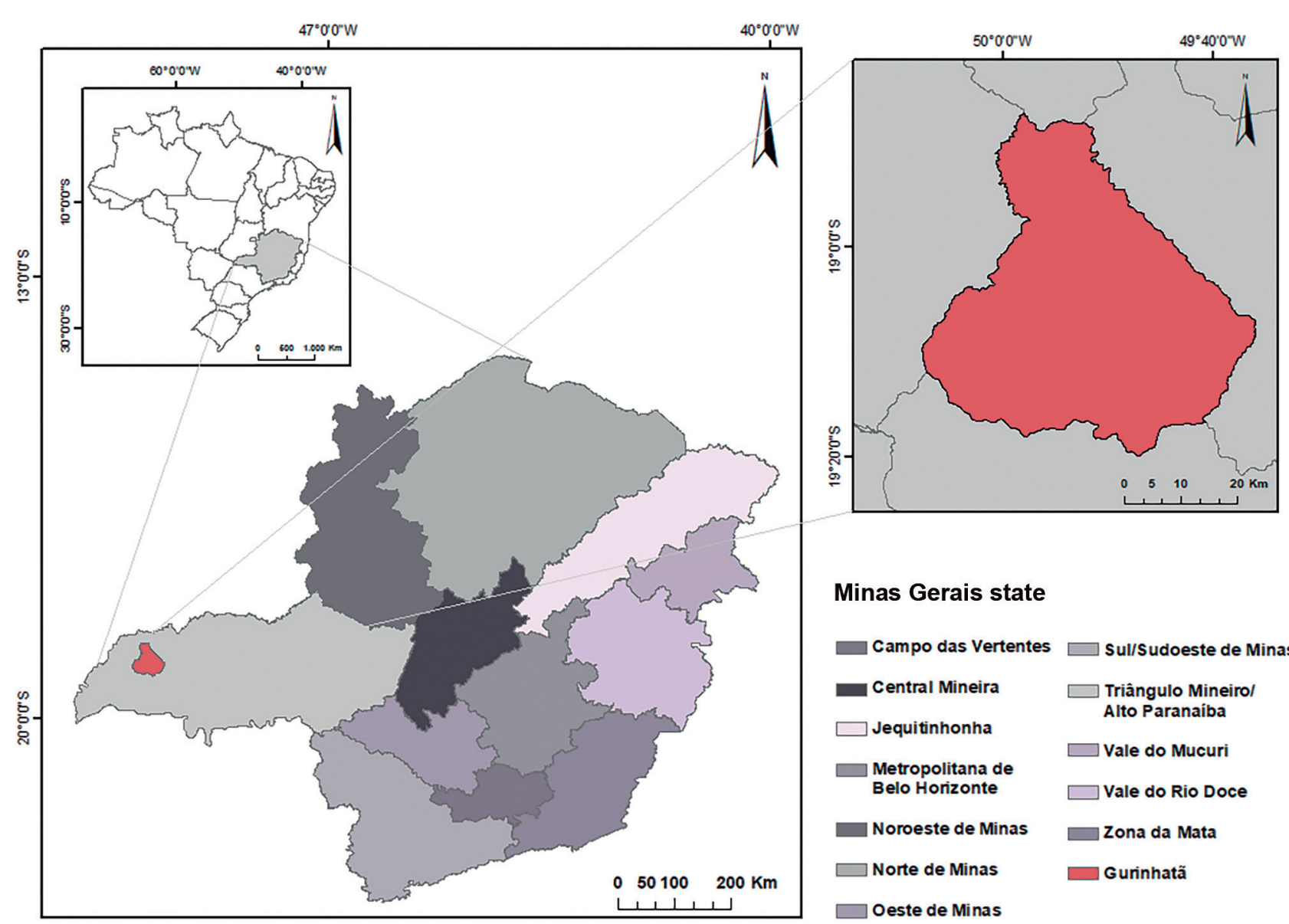

\section{Minas Gerais state}

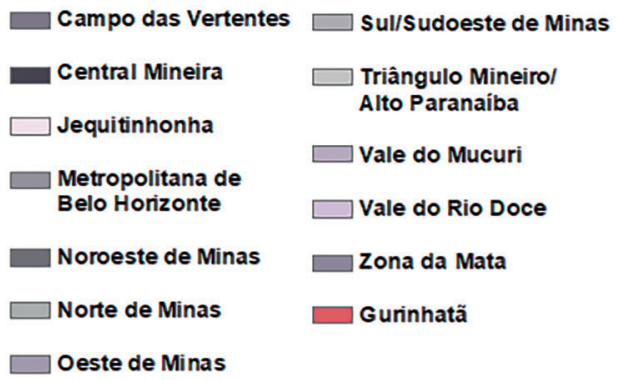

Figure 1. Location map of the municipality of Gurinhatã, Minas Gerais state. Geographic coordinate system: SIRGAS 2000. Source: IBGE/April 2019.

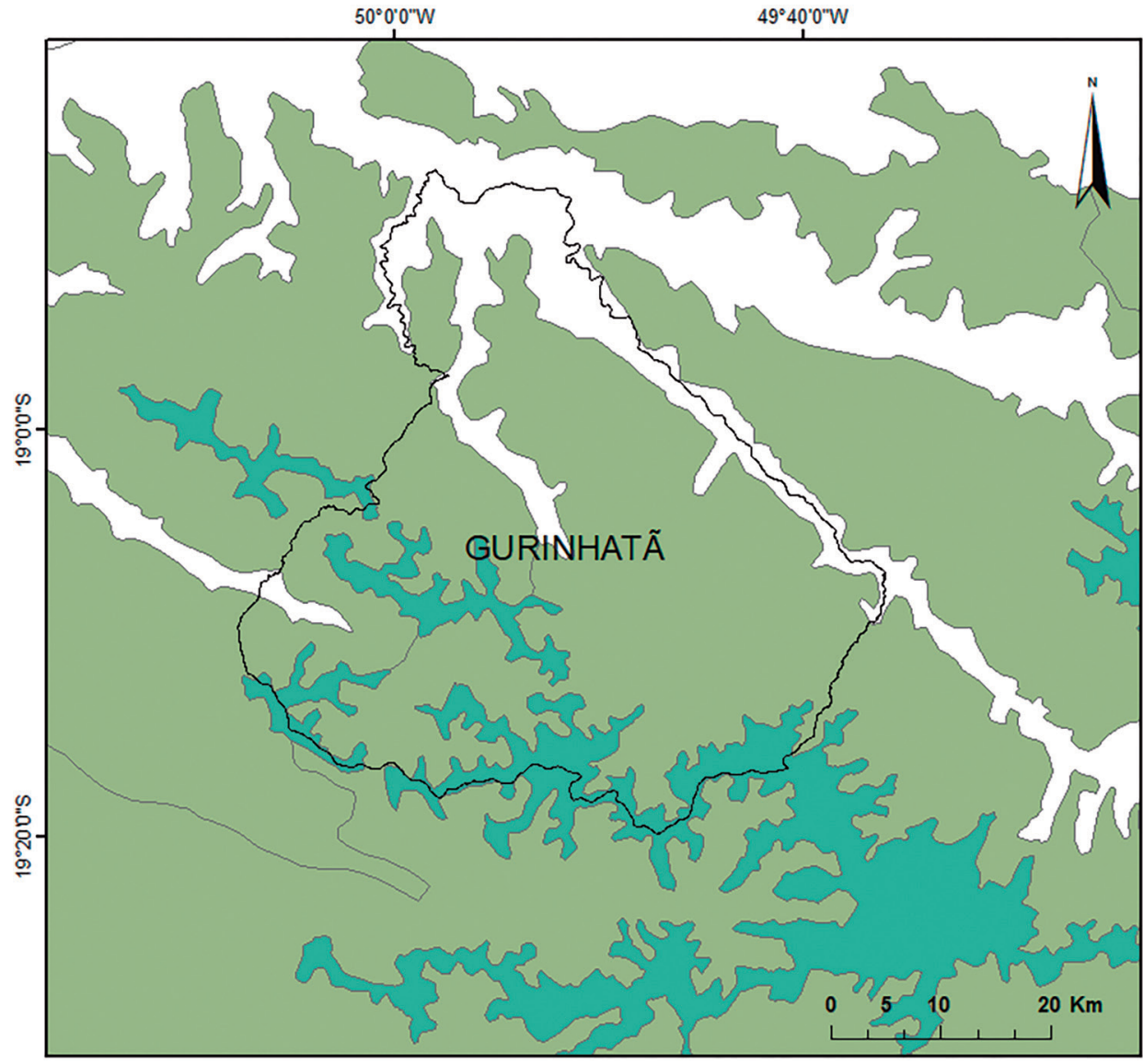

\section{Bauru formation}

Marilia formation

Adamantina formation

Figure 2. Geological map of the Gurinhatã, Detached formations that outcrops in the municipality. Geographic coordinate system: SIRGAS2000. Source: IBGE/April 2019. 
being regionally close to these cited fossiliferous areas, Gurinhatã had not yet yielded any record of dinosaur remains. In 2018, a team of the Laboratory of Paleontology and Evolution of the Geology Course of the Universidade Federal de Goiás (Labpaleoevo-UFG) began a series of prospecting works (2018-2019) of fossils in Gurinhatã. This fieldwork resulted in the discovery of a new outcrop, found approximately $8 \mathrm{~km}$ from the urban area (Fig. 1), where a dinosaur bone was recovered. The specimen (Paleo-UFG/V-0039) consists of a single bone, a quite incomplete ulna. Paleo-UFG/V-0039 was founded isolated, being the first dinosaur record in this locality.

As in other municipalities of the Triangulo Mineiro region, in the region of Gurinhatã, the outcrops are rock expositions of the Bauru Group (Bauru Group, Late Cretaceous, sensu Fernandes \& Coimbra, 1996), a geological unit deposited on the strata of the Paraná Basin (Soares et al., 1980; Fernandes \& Coimbra, 2000; Brusatte et al., 2017). This unit was developed during the Late Cretaceous, deposited during the Gondwana breaking-up (Fernandes \& Coimbra, 2000). The Bauru Group crops out in parts of various Brazilian states, and a detailed stratigraphic review can be seen in some more recent works (e.g., Pinheiro et al., 2018).
Among the eight formations that compose the Bauru Group (sensu Pinheiro et al., 2018), in the Gurinhatã municipality outcrops the Adamantina and Marília formations (Fig. 2). The specimen described in this work comes from strata of the Marília Formation, which strata are mainly dated from Maastrichtian (Dias-Brito et al., 2001; Brusatte et al., 2017), This formation is dominated by sandstones and conglomerates, which are often cemented by carbonate (limestone) and some carbonate concretions (Brusatte et al., 2017; Pinheiro et al., 2018) and interpreted as alluvial fan-like (Riccomini, 1997), later reworked by an interlaced system in association with limestone and lacustrine calcareous sediments (Barcelos \& Suguio, 1987). Lastly, the Marília Formation is traditionally divided into three subunits (Serra da Galga, Ponte Alta \& Echaporã members, sensu Barcelos, 1984). However, more recently, the Serra da Galga and the Ponte Alta members were now part of the Serra da Galga Formation (Soares et al., 2021). Further details on the lithological and stratigraphic aspects of those formations or among the Bauru Group itself can be found in more recent literature (e.g., Brusatte et al., 2017; Pinheiro et al., 2018; Soares et al., 2021) since greater detail is beyond the scope of this work.
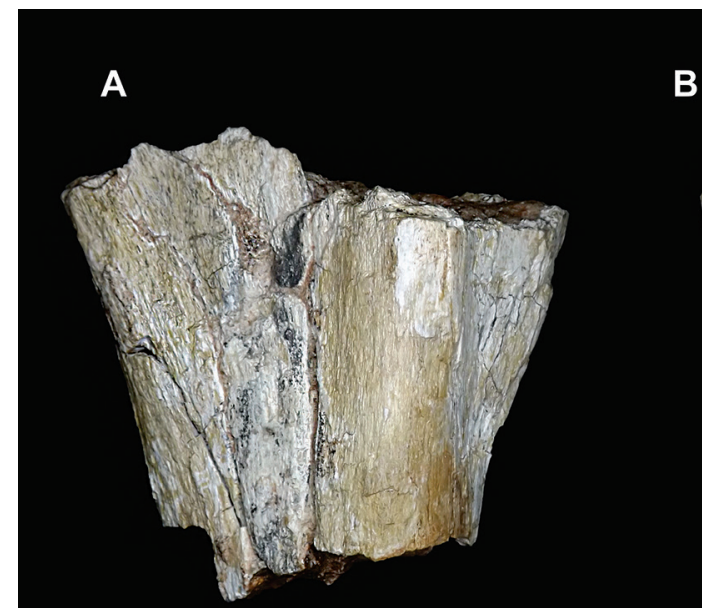

D

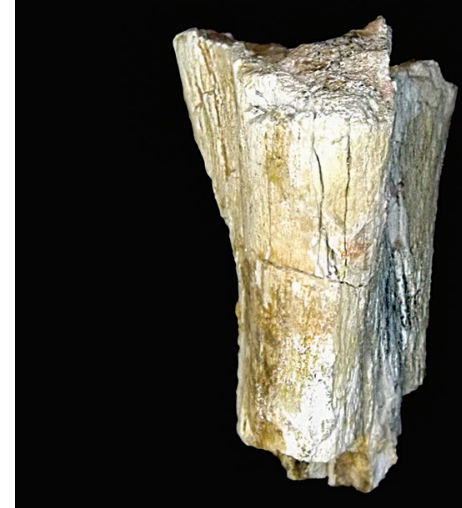

B

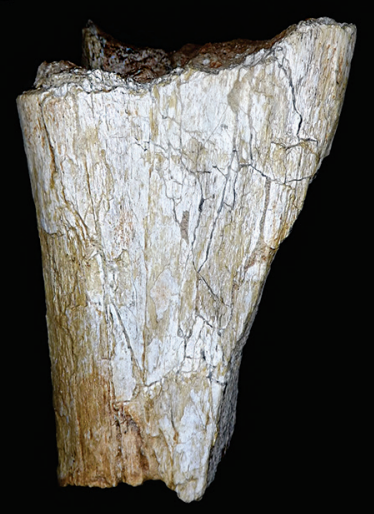

E

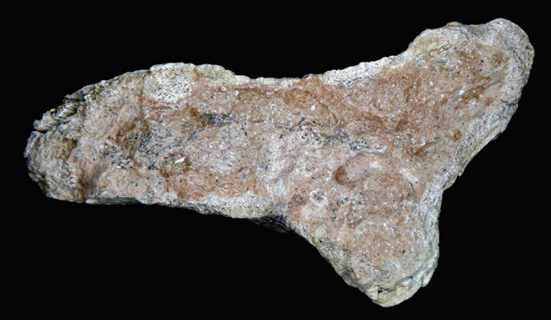

C

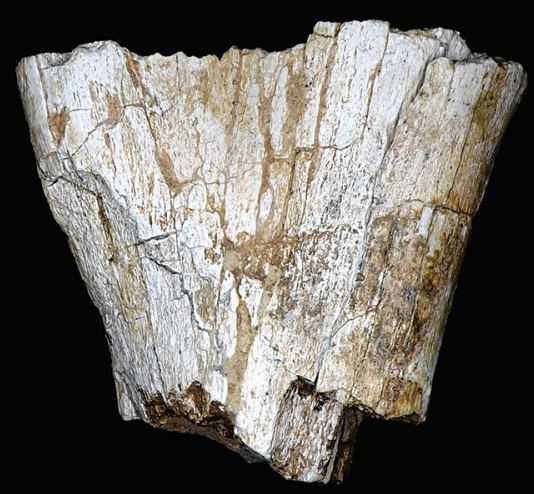

$\mathbf{F}$

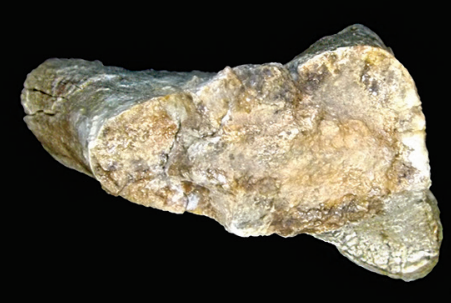

Figure 3. An indeterminate lithostrotian sauropod partial right ulna, Paleo-UFG/V-0039, in (A) Anterior View; (B) Medial View; (C) Posterior View; (D) Lateral View; (E) Proximal View; (F) Distal view. 


\section{Abbreviations}

Anatomical abbreviations: $\mathrm{cmpr}$, craniomedial process; Impr, lateromedial process; popr, caudal process; ol, olecranon; rdfs, radial fossa; mdcc, medial concavity (for m. flexor carpi ulnaris).

Institutional abbreviations: CPP, Centro de Pesquisas Paleontológicas Lewellyn Price, Peirópolis, MG, Brazil; MN, Museu Nacional/UFRJ, Rio de Janeiro, RJ; MPCA, Vertebrate Paleontology collection of the Museo Provincial de Cipolletti "Carlos Ameghino", Río Negro, Argentina; MPMA or MPM, Museu de Paleontologia de Monte Alto, Monte Alto, SP, Brazil; MZSP-PV, Museu de Zoologia da Universidade de São Paulo, São Paulo, SP; Paleo-UFG, Laboratory of Paleontology and Evolution of the Geology Course, Universidade Federal de Goiás, Goiás, Brazil; TMM, Texas Memorial Museum, University of Texas, Austin, USA; UFRJ DG-R, Universidade Federal do Rio de Janeiro, Departamento de Geologia, Rio de Janeiro, RJ, Brazil.

\section{MATERIAL AND METHODS}

The material of Minas Gerais state was collected in the municipalities of Gurinhatã, and are housed under the acronyms Paleo-UFG/V-0039 at the collection of the Laboratório de Paleontologia e Evolução, which is part of the Geology Course of the Aparecida de Goiânia Campus, Federal University of Goiás. Here, we followed the stratigraphic scheme proposed by Soares et al. (1980) and the age suggested by Dias-Brito et al. (2001) it was possible to make comparison by using bibliographic data and taxonomical proposal from Upchurch, Barret \& Dodson (2004).

\section{RESULTS}

Systematic Paleontology

Dinosauria Owen, 1842

Saurischia Seeley, 1888

Sauropoda Marsh, 1878

Titanosauriformes Salgado, Coria \& Calvo, 1997 Somphospondyli Wilson \& Sereno, 1998

Titanosauria Bonaparte \& Coria, 1993

Lithostrotia Upchurch, Barrett, \& Dodson, 2004 Lithostrotia indet.

(Fig. 3)

\section{Description}

Paleo-UFG/V-0039 is recognized as a proximal fragment of the right ulna, based on its morphology. The bone is thin in its central portion and becomes robust proximally. The distalmost part of the fossil is slightly craniocaudally expanded. In a proximal view, the ulna is triradiate and ' $\mathrm{V}$ '-shaped, a feature observed in other titanosauriforms (Upchurch et al., 2015). The irregular fractures in the most distal portion indicate a post-dia- genetic feature, a taphonomic signature less common for the Marilia Formation titanosaur bones (e.g., Bandeira et al., 2018).

Despite incomplete, this morphology indicates that the bone was genuinely wider at the proximal end and narrowed towards its distal end. The craniomedial and craniolateral processes are prominent (Fig. 4); but, as in other sauropods, the caudal process is much more developed and larger than the former (e.g., Poropat et al., 2015; Upchurch et al., 2015; Ullmann \& Lacovara, 2016; González-Riga et al., 2019).

Although this area is not completely preserved, the craniomedial process also is marked by the concave articular surface of the humerus (Fig. 5), while the craniolateral process inclines ventrally, distancing itself from the olecranon, in lateral view (Fig. 3). The caudomedial face exhibits a shallow medial concavity (for insertion of the flexor carpi ulnaris muscle). The ulna shaft is not preserved, but the cross section of the broken distal part of the bone shows that the shaft was subtriangular in this region, due to a caudodistally descending longitudinal crest of the olecranon. The proximal portion of the ascending crest of the olecranon curves slightly medially. In addition, a longitudinal relief ridge defines the medial border of the radial articular face in cranial view.

\section{Comparisons}

Among Brazilian titanosaur species, there are few species that have appendicular materials, and even less those that have directly comparable bones (Table 1). Some other titanosaurs have a visible but slight difference between the craniomedial and craniolateral processes are Aeolosaurus sp. (MPCA-Pv 27174; MPCA-Pv 27175 and MPCA-Pv 27180; García \& Salgado, 2013), Alamosaurus sanjuanensis Gilmore, 1922 (TMM 43621-1, Lehman \& Coulson, 2002), Argyrosaurus superbus Lydekker, 1893 (Mannion \& Otero, 2012), Dreadnoughtus schrani Lacovara \& Ullmann, 2014 (Ullmann \& Lacovara, 2016), Malawisaurus dixeyi Haughton, 1928 (Gomani, 2005), Mendozasaurus neguyelap González-Riga 2003 (González-Riga et al., 2018), Narambuenatitan palomoi Filippi, Garcia \& Garrido, 2011 and Patagotitan mayorum Carballido, Pol, Otero, Cerda, Salgado, Garrido, Ramezani, Cúneo \& Krause, 2017 (Otero et al., 2020). In Argyrosaurus, Diamantinasaurus, Narambuenatitan, Malawisaurus and Mendozasaurus, the difference in length between these processes is more linked to the craniomedial process width, which reaches a maximum robustness in Mendozasaurus. In titanosaurs with stouter appendicular bones, such as Saltasaurus loricatus Bonaparte \& Powell, 1980 (Powell, 2003), Neuquensaurus australis (Lydekker, 1893) (Otero, 2010) and Diamantinasaurus matildae Hocknull, White, Tischler, Cook, Galleja, Sloan \& Elliott 2009 (Poropat et al., 2015), the olecranon process is extremely proximally elevated (e.g., González-Riga et al., 2019) and the craniomedial and craniolateral processes have almost the development.

However, some titanosaurs exhibit a large elongation of the craniomedial process, such as Atsinganosaurus ve- 


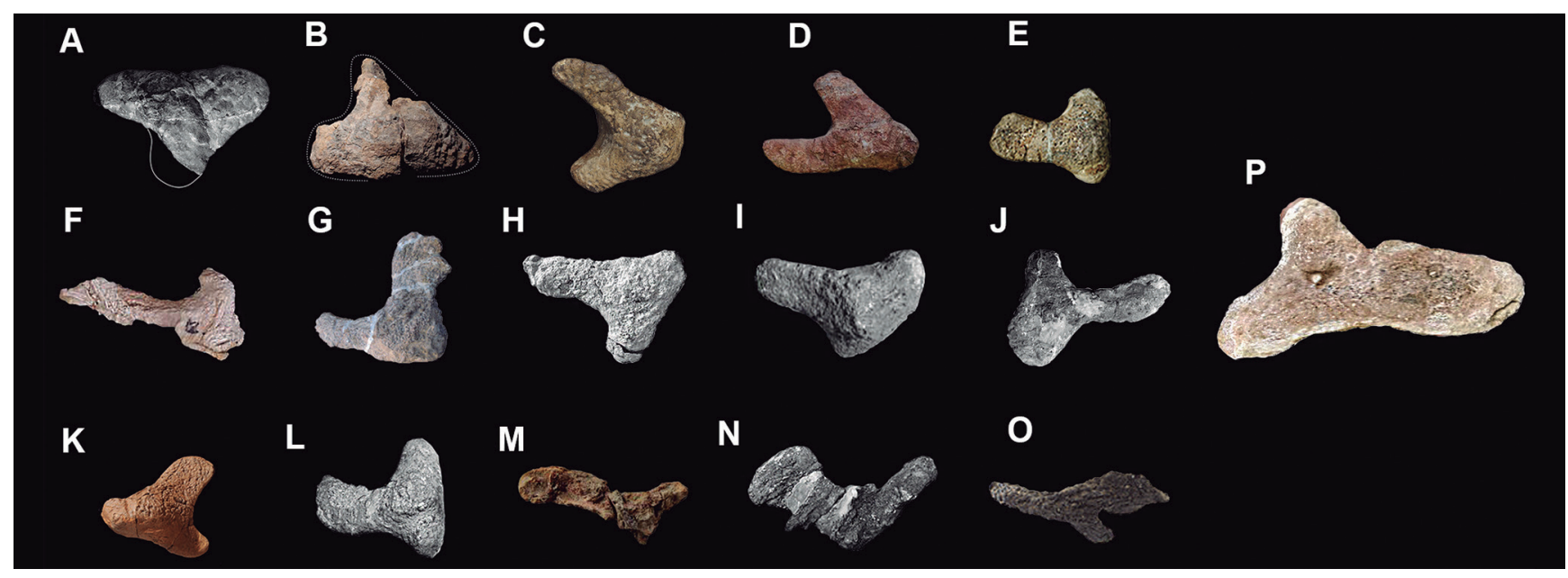

Figure 4. Proximal view of different titanosauriforms for comparison. (A) Sonorosaurus (from D'Emic et al., 2016); (B) Wintonotitan (from Poropat et al., 2014); (C) Haestasaurus (from Upchurch et al., 2015); (D) Yongjinglong (from Li et al., 2014); (E) Angolatitan (from Mateus et al., 2011); (F) Atsinganosaurus (from Díez Díaz et al., 2018); (G) Dreadnoughtus (from Ullmann \& Lacovara, 2014); (H) Rapetosaurus (from Curry Rogers, 2009); (I) Neuquensaurus (from 0tero, 2010); (J) Elaltitan (from Mannion \& Otero, 2012); (K) Diamantinasaurus (from Poropat et al., 2015); (L) Malawisaurus (from Gomani, 2005); (M) Lohuecotitan (from Díez Díaz et al., 2016); (N) Mendozasaurus (from González-Riga et al., 2018); (0) Lirainosaurus (from Díez Díaz et al., 2013); and (P) Paleo-UFG/V-0039. Not in scale.
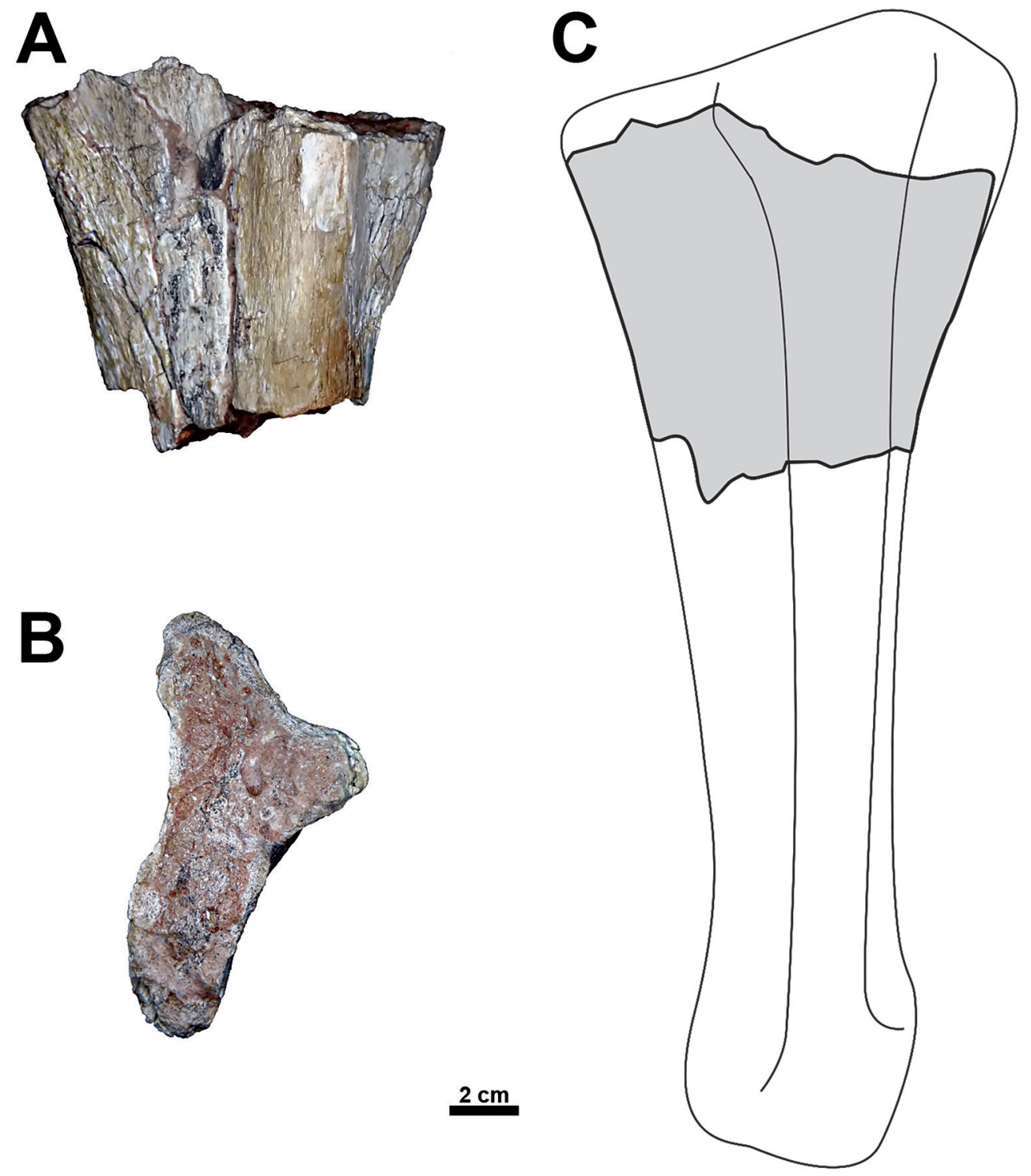

Figure 5. An indeterminate lithostrotian sauropod partial right ulna, paleo-ufg/v-0039, in (A) anterior view; (B) proximal view; (C) explanatory drawning of the right ulna in anterior view. 
Table 1. Brazilian Titanosaur species with appendicular remains.

\begin{tabular}{|c|c|c|c|}
\hline & Species + Described by & Instituition & Skeletal remains \\
\hline 1 & Gondwanatitan faustoi Kellner \& Azevedo, 1999 & Museu Nacional/UFRJ, Rio de Janeiro, RJ & $\begin{array}{l}\text { MN4111-V: } 2 \text { incomplete cervical vertebrae; } 7 \text { dorsal vertebrae; } 6 \text { sacral vertebrae; } 24 \text { caudal } \\
\text { vertebrae; } 4 \text { indeterminate vertebrae; } 1 \text { proximal end of the left scapula; } 1 \text { incomplete left } \\
\text { ilium; } 2 \text { fragmentary pubis; } 2 \text { incomplete ischia; both umera, both tibia; several ribs remains } \\
\text { and several indeterminate remains. }\end{array}$ \\
\hline 2 & $\begin{array}{l}\text { Maxakalisaurus topai Kellner, Campos, Azevedo, Trotta, } \\
\text { Henriques, Craik \& Silva, } 2007\end{array}$ & Museu Nacional/UFRJ, Rio de Janeiro, RJ & $\begin{array}{l}\text { MN 5013-V: } 1 \text { right maxilla with teeth; } 3 \text { almost complete cervical vertebrae; } 9 \text { very } \\
\text { fragmentary cervical vertebrae; } 1 \text { neural spine of sacral vertebra; } 1 \text { centrum from sacral } \\
\text { vertebra; } 6 \text { caudal vertebrae; } 3 \text { haemal arches; } 2 \text { scapulae; } 2 \text { sternal plates; } 1 \text { distal end from } \\
\text { left ischium; } 2 \text { humeri; } 2 \text { metacarpals; } 1 \text { incomplete fibula; } 1 \text { left tibia; 0steoderm. } \\
\text { MN 7048-V: } 1 \text { distal end of right scapula. } \\
\text { MN 7049-V: } 1 \text { sternal plate. } \\
\text { MN 7050-V: } 1 \text { sternal plate. } \\
\text { MN 7051-V: } 1 \text { caudal vertebra. }\end{array}$ \\
\hline 3 & Uberabatintan riberoi Silva-Júnior et al., 2019 & $\begin{array}{l}\text { Centro de Pesquisas Paleontológicas } \\
\text { Lewellyn Price, Peirópolis, MG }\end{array}$ & CPPLIP \\
\hline 4 & $\begin{array}{l}\text { Tapuiasaurus macedoi Zaher, Pol, Carvalho, Nascimento, } \\
\text { Riccomini, Larson, Juarez-Valieri, Pires-Domingues, da } \\
\text { Silva-Jr. \& Campos, } 2011\end{array}$ & $\begin{array}{l}\text { Museu de Zoologia da Universidade de } \\
\text { São Paulo, São Paulo, SP }\end{array}$ & $\begin{array}{l}\text { MZSP-PV 807: } 1 \text { articulated complete skull; } 1 \text { mandible; hioidesaparatus; } 1 \text { atlas; } 1 \text { axis; } \\
5 \text { cervical vertebrae with their respective cervical ribs; } 5 \text { dorsal vertebrae; } 4 \text { dorsal rib; } 1 \text { left } \\
\text { sternal plate; } 1 \text { right coracoid; } 1 \text { right humerus; } 1 \text { left radius; } 2 \text { ulnae; metarcapals; } 2 \text { femora; } \\
1 \text { left fibula; } 1 \text { articulated pes almost complete. }\end{array}$ \\
\hline 5 & Arrudatitan maximus Santucci \& Arruda-Campos, 2011 & $\begin{array}{l}\text { Museu de Paleontologia de Monte Alto, } \\
\text { Monte Alto, SP }\end{array}$ & $\begin{array}{l}\text { MPMA 12-0001-97: } 2 \text { incomplete posterior cervical vertebrae; } 7 \text { incomplete cervical ribs; } \\
1 \text { anterior incomplete dorsal centrum; } 1 \text { incomplete neural arch (?) of middle dorsal vertebra; } \\
1 \text { neural arch of posterior dorsal vertebrae; several incomplete diapophysis of dorsal vertebrae; } \\
12 \text { incomplete dorsal ribs; } 6 \text { articulated anterior caudal vertebrae; } 1 \text { mid caudal centrum; } \\
2 \text { posterior caudal vertebrae; } 8 \text { haemal arches; } 1 \text { fragmentary scapula; } 1 \text { incomplete right } \\
\text { humerus; } 1 \text { incomplete left humerus; } 1 \text { incomplete radius; } 1 \text { incomplete right femur; } 1 \text { well } \\
\text { preserved left femur; } 1 \text { left ischium; and several unidentified fragments. }\end{array}$ \\
\hline 6 & $\begin{array}{l}\text { Brasilotitan nemophagus Machado, Avilla, Nava, Campos } \\
\text { \& Kellner, } 2013\end{array}$ & $\begin{array}{l}\text { Museu de Paleontologia de Marília, } \\
\text { Marília, SP }\end{array}$ & $\begin{array}{l}\text { MPM 125R: } 1 \text { right dentarium; } 2 \text { midcervical vertebrae (Cv5?CV6?); } 3 \text { incomplete sacral } \\
\text { vertebrae; } 1 \text { fragmentary ilium; } 1 \text { fragmentary ischium; } 1 \text { ungueal; ? several unidentified } \\
\text { fragments. }\end{array}$ \\
\hline
\end{tabular}

lauciensis Garcia, Amico, Fournier, Thouand \& Valentin, 2010 (Díez Díaz et al., 2018); Lohuecotitan pandafilandi Díez-Díaz, Mocho, Páramo, Escaso, Marcos-Fernández, Sans \& Ortega, 2016; Lirainosaurus astibiae Sanz, Powell, le Loeuff, Martinez \& Pereda, 1999 (Díez Díaz et al., 2013); Elaltitan lilloi Mannion \& Otero, 2012 and Rapetosaurus krausei Curry Rogers \& Forster, 2001 (Curry Rogers, 2009). This elongation is well-marked in Atsinganosaurus, Lohuecotitan, Elaltitan and in Paleo-UFG/V-0039, where it becomes almost twice the length of the lateromedial process. This development leads to a more compressed morphology craniocaudally, when compared to the ulnae of other titanosaurs.

The medial depression on the shallow descending olecranon crest in Paleo-UFG/V-0039 is similar to that in Rapetosaurus (Curry Rogers, 2009), Saltasaurus (Powell, 2003), Atsinganosaurus (Díez Díaz et al., 2018), Lirainosaurus (Díez Díaz et al., 2013), Lohuecotitan (Díez Díaz et al., 2016), and Neuquensaurus (Otero, 2010). The expression of this concavity as a distinct structure in the proximal region of the ulna is shared only between the new specimen studied here, Elaltitan (Mannion \& Otero, 2012) and Lohuecotitan (Díez Díaz et al., 2016). The clear presence of a high muscular scar on the cranial face of the ulnar axis is shared by Paleo-UFG/V-0039, Dreadnoughtus, Neuquensaurus, and the Aeolosaurus sp. MPCA-Pv 27174; MPCA-Pv 27175 and MPCA-Pv 27180 (Otero, 2010; García \& Salgado, 2013; Ullmann \& Lacovara, 2016). According to Ullmann \& Lacovara (2016), countless titanosaurs as Dreadnoughtus, Neuquensaurus, Isisaurus, Jainosaurus, Narambuenatitan and Aegyptosaurus, have a low longitudinal crest along the cranial ulna denoting the medial limit of the articulation of the radius. Finally, transverse expansion of the distal ulna is a characteristic only observed in opisthocoelicaudiines (Filippi \& Garrido, 2008), which makes it unlikely that the new specimen is within this clade.

\section{DISCUSSION AND CONCLUSION}

Titanosaurs are the only records of sauropod dinosaurs known from the strata of the Bauru Group (Gil \& Candeiro, 2014; Faria et al., 2015; Brusatte et al., 2017; Bandeira et al., 2018; Candeiro et al., 2018). There is a shortage of recovered titanosaurian appendicular material in the Bauru Group as a whole, however, especially when compared with other axial elements (Bandeira et al., 2018). For example, among the eleven Brazilian titanosaur species, six have associated appendicular elements (Table 1), but only Tapuiasaurus has this bone preserved (Zaher et al., 2011). However, little comparison between the Paleo-UFG/V-0039 and Tapuiasaurus is possible, as the ulnae of the later have not been described yet nor properly figured. In this way, although quite incomplete, Paleo-UFG/V-0039 is is important because it is one of the few records of a titanosaur ulna in the Marília Formation, and one of the few titanosaurian appendicular elements found in Bauru Group where there are more abundant axial remains, such as ribs and vertebrae (Bandeira et al., 2018). Also, the quality of bone surface preservation is also comparable to other titanosaurs found in the Bauru Group, where many specimens present a superficial loss of bone tissue (e.g., Bandeira et al., 2016, 2018). 
The morphology of Paleo-UFG/V-0039 exhibits some important features that help place it within Titanosauria. For example, although most sauropods have a craniomedial process that is longer than the craniolateral process, a large elongation of the craniomedial process is restricted to a few taxa (Atsinganosaurus, Lohuecotitan and now Paleo-UFG/V-0039). This finding is important because it may reflect a phylogenetically important character. Many groupings within Titanosauria have been supported chiefly by axial characters, but there may be more appendicular features that provide phylogenetic significance. In the future, more detailed comparative studies focusing on appendicular remains will add useful information for more inclusive phylogenetic analyses.

The specimen Paleo-UFG/V-0039 shows a set of characteristics that allow its attribution to Titanosauria. Adding to this, the fact that to date all records of Late Cretaceous sauropods from the Bauru Group are titanosaurs, it makes sense that the specimen described here belongs to this clade. Moreover, the greater similarity between the morphology of Paleo-UFG/V-0039 and some European species is an illuminating observation, which may speak to phylogenetic links between these sauropods, or perhaps represent convergence between geographically separated species. This and other questions can only be answered by new fossil discoveries in the Gurinhatã region, and throughout the Bauru Group sequences in other areas of Brazil. The discovery of this new specimen, although fragmentary, highlights the possibility of future finds in this municipality, which may impact not only anatomical and taxonomic studies, but also biogeographic hypotheses (if more specimens similar to European species are identified).

\section{ACKNOWLEDGMENTS}

The authors gratefully acknowledge Emerson Oliveira by collection support. This paper was improved by the thoughtful comments from two anonymous reviewers. Our collaborative project was funded by a grant from the Fundação de Amparo à Pesquisa do Estado de Goiás and the Newton Fund, which supported SLB's visit to Brazil to work with CRAC. CRAC was partially supported by the Conselho Nacional de Ciência e Tecnologia by Produtividade e Pesquisa fellow. SLB is also supported by a Marie Curie Career Integration Grants (CIG 630652).

\section{AUTHORS' CONTRIBUTIONS}

Ramon Cavalcanti: Conceptualization, Project administration, Supervision, Writing - Original draft, Writing - Review \& Editing, Investigation, Visualization. Kamila Luisa Nogueira Bandeira: Writing - Review \& Editing, Investigation, Validation. Carlos Roberto Candeiro dos Anjos: Funding aquisition, Resource, Writing - Review \& Editing. Luciano Vidal: Writing - Review \& Editing. Musa Maria:Writing - Review \& Editing. Steve Bursatte: Writing - Review \& Editing. All the authors actively participated in the discussion of the results, they reviewed and approved the final version of the paper.

\section{CONFLICTS OF INTEREST}

Authors declare there are no conflicts of interest.

\section{REFERENCES}

Bandeira, K.L.N.; Brum, A.S.; Pêgas, R.V.; Cidade, G.M.; Holgado, B.; Cidade, A. \& Souza, R.G. 2018. The Baurusuchidae vs. Theropoda record in the Bauru Group (Upper Cretaceous, Brazil): a taphonomic perspective. Journal of Iberian Geology, 44(1): 25-54. D0I

Bandeira, K.L.N.; Simbras, F.M.; Machado, E.B.; Campos, D.A.; Oliveira, G.R. \& Kellner, A.W.A. 2016. A New Giant Titanosauria (Dinosauria: Sauropoda) from the Late Cretaceous Bauru Group, Brazil. PLOS ONE, 11(10): e0163373. DOI

Barcelos, J.H. 1984. Reconstrução paleogeográfica da sedimentação do Grupo Bauru baseada na sua redefinição estratigráfica parcial em território paulista e no estudo preliminar fora do estado de São Paulo. Rio Claro. Thesis (Livre Docência). Rio Claro, Universidade Estadual Paulista.

Barcelos, J.H. \& Suguio, K. 1987. Correlação e extensão das unidades litoestratigráficas do Grupo Bauru, definidas em território paulista, nos estados de Minas Gerais, Goiás, Mato Grosso do Sul e Paraná. In: Simpósio Regional de Geologia, 60. Atas. São Pedro, SP, UNESP. p. 313-321.

Brusatte, S.L.; Candeiro, C.R.A. \& Simbras, F.M. 2017. The last dinosaurs of Brazil: the Bauru Group and its implications for the end-Cretaceous mass extinction. Anais da Academia Brasileira de Ciências, 89: 1465-1485. DOI

Campos, D.A.; Kellner, A.W.A.; Bertini, R.J. \& Santucci, R.M. 2005. On a titanosaurid (Dinosauria, Sauropoda) vertebral column from the Bauru Group, Late Cretaceous of Brazil. Arquivos do Museu Nacional, 63(3): 565-593.

Candeiro, C.R.A. 2007. Cretaceous biota of the Triângulo Mineiro region: A review of recent finds. Estudios Geologicos, 63: 65-73.

Candeiro, C.R.A. \& Figueiroa, S.F.M. 2017. Earlyy twentieth-century paleontological research of Freidrich von Huene: contributions to the knowledge of Late Cretaceous vertebrates of Central Brazil. Historical Biology, 29: 1-10. DOI

Candeiro, C.R.A.; Alves, D.S.J.; Figueiroa, S.F.M. \& Gil, L.M. 2019. First record of sauropod remains from the Maastrichtian Marília Formation (Bauru Group) of Monte Alegre de Minas since Friderich von Huene's description in 1931. Anuário do Instituto de Geociências, 42(2): 325-332. D0I

Candeiro, C.R.A.; Brusatte, S.L.; Queiroz, G.K.; Carvalho, A.A.; Maia, D.S.; Dias, T.C.; Vidal, L.S. \& Nogueira-Gomes, M.M. 2020. Late Cretaceous Bauru Group biota from Southern Goiás state, Brazil: history and fossil content. Earth Sciences Research Journal, 24(4): 387-396. D0I

Candeiro, C.R.A.; Brusatte, S.L.; Simbras, F.M.; Santos-Pereira, C.; Souza-Jr., A.L.; Cavalcanti, R.; Carelli, D.; Resende, I.L.M.; Nogueira-Gomes, M.M.; Souza, J.B.F.; Gil, L.M.; Rossi, R.; Hannibal, W.; Costa, R.R. \& Oliveira, G. 2018. New reports of Late Cretaceous reptiles from the Bauru Group of southern Goiás State, Brazil. Journal of South American Earth Sciences, 85: 229-235. DOI

Curry Rogers, K. 2009. The postcranial osteology of Rapetosaurus krausei (Sauropoda: Titanosauria) from the Late Cretaceous of Madagascar. Journal of Vertebrate Paleontology, 29(4): 1046-1086. D0I

Delcourt, R. \& Iori, F.V. 2018. A new Abelisauridae (Dinosauria: Theropoda) from São José do Rio Preto Formation, Upper Cretaceous of Brazil and comments on the Bauru Group fauna. Historical Biology, 1-8. D0I 
Dias-Brito, D.; Musacchio, E.A.; Castro, J.C.; Maranhão, M.S.A.S.; Suarez, J.M. \& Rodrigues, R. 2001. Bauru Group: a continental cretaceous init in Brazil - concepts based on micropaleontological, oxygen isotopeand stratigraphical data. Revue de Paléobiologie, Genève, 20(1): 245-304.

Díez Díaz, V.; Garcia, G.; Suberbiola, X.P.S.; Jentgen-Ceschino, B.; Stein, K.; Godefroit, P. \& Valentin, X. 2018. The titanosaurian dinosaur Atsinganosaurus velauciensis (Sauropoda) from the Upper Cretaceous of southern France: New material, phylogenetic affinities, and palaeobiogeographical implications. Cretaceous Research, 91: 429-456. DOI

Díez Díaz, V.; Mocho, P.; Páramo, A.; Escaso, F.; Marcos-Fernández, F.; Sanz, J.L. $\&$ Ortega, F. 2016. A new titanosaur (Dinosauria, Sauropoda) from the Upper Cretaceous of Lo Hueco (Cuenca, Spain). Cretaceous Research, 68: 49-60. D0I

Díez Díaz, V.; Pereda Suberbiola, X. \& Sanz, J.L. 2013. Appendicular skeleton and dermal armour of the Late Cretaceous titanosaur Lirainosaurus astibiae (Dinosauria: Sauropoda) from Spain. Palaeontologia Electronica, 16(2): 19-37. DOI

Faria, C.C.J.; Gonzalez-Riga, B.; Candeiro, C.R.A.; Marinho, T.S.; David, L.0.; Simbras, F.M.; Castanho, R.B.; Muniz, F.P. \& Pereira, P.V.L.G.C. 2015. Cretaceous sauropod diversity and taxonomic succession in South America. Journal of South American Earth Sciences, 61: 154-163. D0I

Fernandes, L.A. \& Coimbra, A.M. 1996. A Bacia Bauru (Cretáceo Superior, Brasil). Anais da Academia Brasileira de Ciências, 8(2): 195-205.

Fernandes, L.A. \& Coimbra, A.M. 2000. Revisão estratigráfica da parte oriental da Bacia Bauru (Neocretáceo). Revista Brasileira de Geociências, 30(4): 717-728.

Filippi, L.S. \& Garrido, A.C. 2008. Pitekunsaurus macayai gen. et sp. nov., nuevo titanosaurio (Saurischia, Sauropoda) del Cretácico Superior de la Cuenca Neuquina, Argentina. Ameghiniana, 45(3): 575-590.

García, R.A. \& Salgado, L. 2013. The titanosaur sauropods from the Allen Formation (late Campanian-early Maastrichtian) of Salitral Moreno (Patagonia, Río Negro, Argentina). Acta Palaeontologica Polonica, 58(2): 269-284. DOI

Gil, L.M.\& Candeiro, C.R.A. 2014. Os titanosssaurídeos (Dinosauria, Sauropoda, Titanosauria) do (retáceo Superior do Triângulo Mineiro: registro fóssil, distribuição e história natural. Biota Amazônia, 4(2): 80-90.

Gomani, E.M. 2005. Sauropod Dinosaurs from the Early Cretaceous of Malawi, Africa. Paleontologia Eletronica, 8(1): 37.

González-Riga, B.J.; Lamanna M.C.; Otero A.; Ortiz, D.L.;, Kellner, A.W.A. \& Ibiricu, L.M. 2019. An overview of the appendicular skeletal anatomy of South American titanosaurian sauropods, with definition of a newly recognized clade. Anais da Academia Brasileira de Ciências, 91(Suppl. 2):1-42 e20180374. DOI

González-Riga, B.J.; Mannion, P.D.; Poropat, S.F.; Ortiz, D.L. \& Coria, J.P. 2018. Osteology of the Late Cretaceous Argentinean sauropod dinosaur Mendozasaurus neguyelap: implications for basal titanosaur relationships. Journal of the Linnean Society, 184(1): 136-181. D0I

Instituto Brasileiro de Geografia e Estatística (IBGE). 2019. Available: ftp://ftp. ibge.gov.br/Cartas e Mapas/Mapas Tematicos. Access: 04/2019.

Kellner, A.W.A. \& Campos, D.A. 2000. Brief Review of Dinosaur Studies and Perspectives in Brazil. Anais da Academia Brasileira de Ciências, 72(4):509-538.

Lehman, T.M. \& Coulson, A.B. 2002. A juvenile specimen of the sauropod dinosaur Alamosaurus sanjuanensis from the Upper Cretaceous of Big Bend National Park, Texas. Journal of Paleontology, 76(1): 156-172. DOI

Mannion, P.D. \& Otero, A. 2012. A reappraisal of the Late Cretaceous Argentinean sauropod dinosaur Argyrosaurus superbus, with a description of a new titanosaur genus. Journal of Vertebrate Paleontology, 32(3): 614-638. DOI

Otero, A. 2010. The appendicular skeleton of Neuquensaurus, a Late Cretaceous saltasaurine sauropod from Patagonia, Argentina. Acta Palaeontologica Polonica, 55(3): 399-426. DOI

Otero, A.P.; Carballido, J.L. \& Pérez Moreno, A. 2020. The appendicular osteology of Patagotitan mayorum (Dinosauria, Sauropoda). Journal of Vertebrate Paleontology, 40(4): 1-19. e1793158. D0I

Peyerl, D.; Candeiro, C.R. \& Figueiroa, S.F.M. 2015. Trajectory and contribution of geoscientists (1906-1961) to dinosaur research in the Bauru Group (Cretaceous) in the Triângulo Mineiro region of Brazil. Journal of South American Earth Sciences, 61: 64-70. DOI

Pinheiro, A.E.P.; Pereira, P.V.L.G.C.; Souza, R.G.; Brum, A.S.; Lopes, R.T.; Machado, A.S.; Bergqvist, L.P. \& Simbras, F.M. 2018. Reassessment of the enigmatic crocodyliform "Goniopholis" paulistanus Roxo, 1936: historical approach, systematic, and description by new materials. PLOS ONE, 13(8): e0199984. DOI

Poropat, S.F.; Upchurch, P.; Mannion, P.D.; Hocknull, S.A.; Kear, B.P.; Sloan, T.; Sinapius, G.H.K. \& Elliot, D.A. 2015. Revision of the sauropod dinosaur Diamantinasaurus matildae Hocknull et al., 2009 from the midCretaceous of Australia: Implications for Gondwanan titanosauriform dispersal. Gondwana Research, 27(3): 995-1033. D0I

Powell, J.E. 2003. Revision of South American titanosaurid dinosaurs: paleobiological, palaeobiogeographical and phylogenetic aspects. Records of the Queen Victoria Museum, 111: 1-173.

Riccomini, C. 1997. Arcabouço estrutural e aspectos do tectonismo gerador e deformador da Bacia Bauru no estado de São Paulo. Revista Brasileira de Geociências, 27(2): 153-162.

Santucci, R.M. \& Arruda-Campos, A.C.A. 2011. New sauropod (Macronaria, Titanosauria) from the Adamantina Formation, Bauru Group, Upper Cretaceous of Brazil and the phylogenetic relationships of Aeolosaurini. Zootaxa, 3085: 1-33. DOI

Silva-Júnior, J.; Marinho, T.; Martinelli, A. \& Langer, M. 2019. Osteology and systematics of Uberabatitan ribeiroi (Dinosauria; Sauropoda): A Late Cretaceous titanosaur from Minas Gerais, Brazil. Zootaxa, 4577: 401-438. DOI

Soares, P.C.; Landim, P.M.B.; Fúlfaro, V.J. \& Sobreiro-Neto, A.F. 1980. Ensaio de caracterização estratigráfica do Cretáceo no estado de São Paulo: Grupo Bauru. Revista Brasileira de Geociências, 10(3): 177-185.

Soares, M.V.T.; Basilici, G.; Marinho, T.S.; Martinelli, A.G.; Marconato, A.; Mountney, N.G.; Colombera, L.; Mesquita, A.F.; Vasques, J.T.; Abrantes, F.R.J.; Ribeiro, L.C.B. 2021. Sedimentology of a distribuitive fluvial system: The Serra da Galga Formation, a new lithostratigraphic unit (Upper Cretaceous, Bauru Basin, Brazil). Geological Journal, 56(2): 951-975. D01

Ullmann, P.V. \& Lacovara, K.J. 2016. Appendicular osteology of Dreadnoughtus schrani, a giant titanosaurian (Sauropoda, Titanosauria) from the Upper Cretaceous of Patagonia, Argentina. Journal of Vertebrate Paleontology, 36(6): 1-23. e1225303. DOI

Upchurch, P.; Mannion, P.D.\& Taylor, M.P. 2015. The anatomy and phylogenetic relationships of "Pelorosaurus" becklesii (Neosauropoda, Macronaria) from the Early Cretaceous of England. PLOS ONE, 10: e0125819. DOI

Zaher, H.; Pol, D.; Carvalho, A.B.; Nascimento, P.M.; Riccomini, C.; Larson, P.; Juarez-Valieri, R.; Pires-Domingues, R.; Silva, J.N. \& Campos, D.A. 2011. A Complete skull of an early cretaceous Sauropod and the evolution of advanced Titanosaurians. PLOS ONE, 6: e16663. DOI 